\title{
Serum Copper, Zinc, and Iron Levels in Patients with Alzheimer's Disease: A Meta-Analysis of Case-Control Studies
}

\author{
Dan-Dan $\mathrm{Li}^{1 \dagger}$, Wei Zhang ${ }^{2+}$, Zhan-You Wang ${ }^{1 *}$ and Pu Zhao ${ }^{1 *}$ \\ ${ }^{1}$ College of Life and Health Sciences, Northeastern University, Shenyang, China, ${ }^{2}$ Department of Hepatobiliary Surgery, \\ General Hospital of Shenyang Military Area Command, Shenyang, China
}

Background: Many publications have investigated the association between metal ions and the risk of Alzheimer's disease (AD), but the results were ambiguous.

Aims: The objective of this study was to assess the association between the serum levels of metals (copper/zinc/iron) and the risk of $A D$ via meta-analysis of case-control studies.

Methods: We screened literatures published after 1978 in the Pubmed, Embase, Cochrane library, Web of Science and ClinicalTrials.gov. Electronic databases. By using Preferred Reporting Items for Systematic reviews and Meta-Analyses (PRISMA)

\section{OPEN ACCESS}

Edited by:

Milica S. Prostran

University of Belgrade, Serbia

Reviewed by:

Cathy W. Levenson,

Florida State University, United States

Branislava M. Medic, Department of Pharmacology, Clinical Pharmacology and Toxicology, Serbia

*Correspondence:

Zhan-You Wang

wangzy@mail.neu.edu.cn

Pu Zhao

zhaopu6687700@mail.neu.edu.cn

${ }^{\dagger}$ These authors have contributed equally to this work.

Received: 19 February 2017

Accepted: 31 August 2017

Published: 15 September 2017

Citation:

Li D-D, Zhang W, Wang Z-Y and Zhao P (2017) Serum Copper, Zinc,

and Iron Levels in Patients with Alzheimer's Disease: A Meta-Analysis of Case-Control Studies.

Front. Aging Neurosci. 9:300 doi: 10.3389/fnagi.2017.00300 guidelines, we performed a systematic review of the 407 publications, there are 44 of these publications met all inclusion criteria. The Review Manager 5.3 software was used to calculate available data from each study.

Results: Consistent with the conclusions of other meta-analysis, our results demonstrated serum copper levels were significantly higher $[M D=9.27,95 \% \mathrm{Cl}$ (5.02-13.52); $p<0.0001$ ], and the serum zinc levels were significantly lower in $A D$ patients than in healthy controls $[\mathrm{MD}=-6.12,95 \% \mathrm{Cl}(-9.55,-2.69) ; p=0.0005]$. Serum iron levels were significantly lower in AD patients than in healthy controls after excluded two studies [MD $=-13.01,95 \% \mathrm{Cl}(-20.75,-5.27) ; p=0.001]$.

Conclusion: The results of our meta-analysis provided rigorous statistical support for the association of the serum levels of metals and the risk of $A D$, suggesting a positive relationship between the serum copper levels and $A D$ risk, and a negative relationship between the serum zinc/iron levels and AD risk.

Keywords: copper, zinc, iron, Alzheimer's disease, meta-analysis

\section{INTRODUCTION}

Alzheimer's disease (AD) is a progressive neurodegenerative disorder that leads to intellectual decline including memory loss, and language breakdown (International, 2009) ${ }^{1}$. Besides cognitive decline, $\mathrm{AD}$ patients have many other different manifestations, including mood disturbance and psychological symptoms (Paulsen et al., 2000; Tractenberg et al., 2002).

${ }^{1}$ International, A. S. D. (2009). World Alzheimer Report 2009. 
The deposition of $\beta$-amyloid peptide $(A \beta)$ in the brain is one of the pathology hallmarks of AD (Citron, 2010; Buendia et al., 2016; Sepulcre et al., 2016; Kreutzer et al., 2017). Although high concentrations of endogenous copper (Cu) (Pal et al., 2015; Greenough et al., 2016; Xu et al., 2016), zinc (Zn) (Kulikova et al., 2015; Mezentsev et al., 2016), and iron (Fe) (Guo et al., 2015; Peters et al., 2015; Sands et al., 2016; James et al., 2017) have been found in these amyloidal plaques, the association of those metal ions with $A \beta$ accumulation has not been well established. Recent studies (Exley, 2006; Alimonti et al., 2007; Azhdarzadeh et al., 2013; McCord and Aizenman, 2014; Yuan et al., 2014; Koç et al., 2015; Paglia et al., 2016) indicated that these bioactive metals are definitely important for the function of the brain, and are critical for $A \beta$ aggregation and reactive oxygen species (ROS) production in the brains of $\mathrm{AD}$ patients and $\mathrm{AD}$ mouse model. For example, lacking of $\mathrm{Zn}$ can cause neuronal death and mild cognitive impairment (MCI) which occurs in elderly people (Sparks et al., 2006; Brewer, 2012). And for $\mathrm{Cu}$, it can interact with $\mathrm{A} \beta$, mediates the aggregation of $\mathrm{A} \beta$ under slightly acidic conditions, and facilitates the generation of oxidative stress (Cheignon et al., 2016). For $\mathrm{Fe}$, it is another essential ion that participates the cellular processes of neurons, and its importance was recently being realized by scientific communities, as it can catalyze fenton-based reactions to generate ROS (Gonzalez-Dominguez et al., 2014). Studies showed that Fe can accumulate in $A \beta$ plagues (Shore et al., 1984; Jeandel et al., 1989; Molaschi et al., 1996; Gonzalez et al., 1999) and neurons with neurofibrillary tangles (Gonzalez-Dominguez et al., 2014), bind with the ironresponsive element RNA stem loop in the $5^{\prime}$-UTR of amyloid$\beta$ protein precursor $(\mathrm{A} \beta \mathrm{PP}) \mathrm{mRNA}$, and then regulate the translation of A $\beta$ PP (Molina et al., 1998; Squitti et al., 2013b) and $\mathrm{AD}$ progression.

On the basis of these evidences, the potential role of $\mathrm{Cu} / \mathrm{Zn} / \mathrm{Fe}$ dysfunction in the pathogenesis of $\mathrm{AD}$ has been the object of much investigation over the past decades. Therefore, the aim of our study was to provide more useful information about the relationship between the serum levels of $\mathrm{Cu} / \mathrm{Zn} / \mathrm{Fe}$ and $\mathrm{AD}$ susceptibility by carried out the present meta-analysis of casecontrol studies published in the past few years on the role of $\mathrm{Cu}$, $\mathrm{Zn}$, and $\mathrm{Fe}$ in $\mathrm{AD}$.

\section{MATERIALS AND METHODS}

\section{Search Strategy}

We searched for case-control studies articles published from 1978 to May 2016 via systematically screening in the PUBMED, EMBASE, Cochrane library, Web of science and clinical trials.gov electronic databases according to PRISMA guidelines (Moher et al., 2010) by using the following search terms In the keywords "Alzheimer's disease"(or "AD"), "copper" (or "Cu” or "Cu ${ }^{2+”), ~}$ “zinc" (or “ $\mathrm{Zn}$ ” or “ $\mathrm{Zn}^{2+}$ ), "iron” (or "Fe" or “ $\mathrm{Fe}^{2+}$ ”), "metals." Additional studies were obtained from the reference lists of identified studies.

\section{Selection Criteria}

According to PRISMA guideline (Moher et al., 2010), we choose the following inclusion criteria for the meta-analyses: (1) full-text publications written in English; (2) case-control studies about the association of $\mathrm{Cu}, \mathrm{Zn}$, and $\mathrm{Fe}$ with the $\mathrm{AD}$; (3) studies providing the serum level of $\mathrm{Cu}, \mathrm{Zn}$, and $\mathrm{Fe}$ to calculate the mean difference (MD) or standardized mean difference (SMD) and $95 \%$ confidence intervals (CIs).

Studies were excluded for the following reasons: (1) noncase-control studies trials, such as case reports, reviews, and meta-analysis; (2) family-based studies; (3) without original data; (4) non-human; and (5) were published in a language other than English.

\section{Study Selection and Data Extraction}

Studies were identified by two independent authors using the aforementioned search strategy. When there was uncertainty regarding eligibility, the other two authors were consulted. The following information was collected from each study: name of the first author; year of publication; country; criteria for $\mathrm{AD}$ diagnosis, sample sizes of patients and controls, mean age, and percentage of females in groups. We assessed how metal levels were measured with the following data: type of sample; assay method; laboratory or kit used; collection, process, and storage of sample; blinding of laboratory personnel; and the use of quality control sample. Data in other forms [i.e., odds ratio and mean $\pm 95 \%$ confidence interval (CI)] were converted to mean $\pm \mathrm{SD}$ according to the Cochrane Handbook (Higgins and Green, 2009). If data were not reported numerically, we extracted them by manual measurements from published figures.

\section{Statistical Analysis}

The meta-analyses were done using the Review Manager 5.3 software. Total MD with 95\% CIs were determined to evaluate the strength of the association between $\mathrm{Cu} / \mathrm{Zn} / \mathrm{Fe}$ and $\mathrm{AD}$ risk. Heterogeneity was assessed with the Cochran Q-statistic and the $\mathrm{I}^{2}$ test (Coory, 2010). Studies with an $\mathrm{I}^{2}$ value $<25 \%$ were considered to have low heterogeneity, and those with an $\mathrm{I}^{2}>75 \%$ were considered to have a high degree of heterogeneity. If there is $P_{\mathrm{Q}}>0.05$ among the involved studies in the meta-analysis, the fixed-effect model is used; otherwise, the random-effect model is adopted. If there is significant heterogeneity, we omitted each individual study in turn from the total, and reanalyzed the remainder. All statistical analyses were conducted with Review Manager 5.3 software and the two-sided $P<0.05$ in the $Z$-test was deemed to be statistically significant.

\section{RESULTS}

\section{Study Identification and Selection}

The procedures for the study selection are displayed in Figure 1. The initial search yielded 406 relevant publications form the PUBMED, EMBASE, Cochrane library, Web of science and clinical trials.gov. Duplicate references were automatically removed. The title and abstract of the remaining 356 publications were evaluated according to predefined exclusion and inclusion criteria. Then, 278 publications were excluded, 34 were subsequently excluded and 44 (Shore et al., 1984; Jeandel et al., 1989; Kapaki et al., 1989; Molaschi et al., 1996; Thome et al., 1996; Molina et al., 1998; Gonzalez et al., 1999; Maes et al., 1999; Ozcankaya and Delibas, 2002; Squitti et al., 2002a,b, 2005, 2006, 2007, 2010, 2011, 2013a,b; Smorgon et al., 2004; Bocca et al., 2005; 


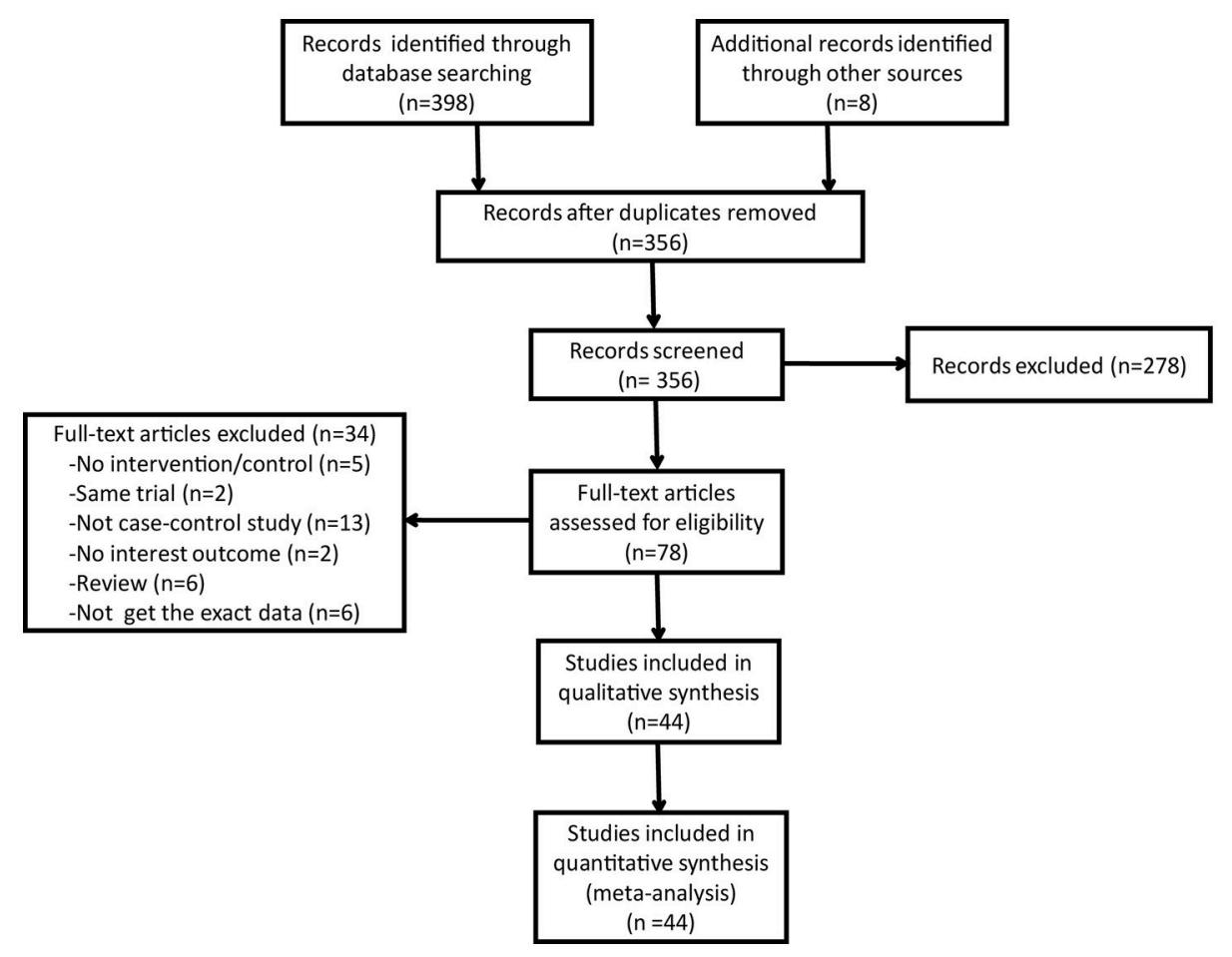

FIGURE 1 | Study selection for systematic review.

Sedighi et al., 2006; Alimonti et al., 2007; Sevym et al., 2007; Agarwal et al., 2008; Dong et al., 2008; Zappasodi et al., 2008; Baum et al., 2010; Brewer et al., 2010a,b; Giambattistelli et al., 2012; Mueller et al., 2012; Azhdarzadeh et al., 2013; Huang et al., 2013; Lopez et al., 2013; Rembach et al., 2013, 2014; Crespo et al., 2014; Gonzalez-Dominguez et al., 2014; Park et al., 2014; Singh et al., 2014; Koç et al., 2015; Wang et al., 2015; Paglia et al., 2016; Siotto et al., 2016) were included in the systematic review and meta-analysis.

\section{Studies on Cu in Serum}

Characteristics of the 35 included studies are summarized in Table 1. As show in Figure 2, 35 form 34 articles with a total of 2,128 AD patients and 2,889 healthy controls were included in serum $\mathrm{Cu}$ meta-analysis. To note, the paper by Azhdarzadeh et al. (2013) consisted of two study groups and each group was detected separately. The patient sample sizes of the included studies are ranged from 5 (Kapaki et al., 1989) to 399 (Squitti et al., 2013b) and control sample sizes from 10 (Shore et al., 1984) to 716 (Rembach et al., 2013). The mean age of the patient groups was $>54$. The percentage of female $\mathrm{AD}$ patients ranged from $20 \%$ (Kapaki et al., 1989) to 100\% (Molaschi et al., 1996).

Of the 35 included studies, results are discordant, as shown in Table 1, 26 studies reported an increase of serum $\mathrm{Cu}$ levels in $\mathrm{AD}$ patients. The other 9 studies reported a decrease of serum $\mathrm{Cu}$ levels in $\mathrm{AD}$ patients, but two of the studies reported a tiny increase. Combined analysis of the relationship between the serum $\mathrm{Cu}$ level and $\mathrm{AD}$ was shown in a forest plot (Figure 2). The meta-analysis demonstrated $\mathrm{Cu}$ levels were significantly higher in $\mathrm{AD}$ patients than controls $[\mathrm{MD}=9.27,95 \% \mathrm{CI}(5.02-13.52)$; $p<0.0001]$. As a high heterogeneity between the included studies was observed $\left(\mathrm{I}^{2}=98 \%\right)$, we ran a sensitivity analysis and found that the $\mathrm{I}^{2}=89 \%$ after excluding the study of Singh et al. (2014) and Ozcankaya and Delibas (2002). After the exclusion, the result of this meta-analysis showed that serum $\mathrm{Cu}$ levels were significant higher in $\mathrm{AD}$ patients $[\mathrm{MD}=9.13$; 95\% CI (6.17, 12.09); $p<0.00001$ ]. Publication bias was assessed graphically using a funnel plot (Figure 3). Moreover, we ran a subgroup analysis for the country $(p=0.13)$, the mean age of the subjects $(p=0.66)$, and the percentage of women $(p=0.18)$ as a possible confounder, which revealed no variation of serum $\mathrm{Cu}$ level strictly associated with them.

\section{Studies on $\mathbf{Z n}$ in Serum}

Characteristics of the 22 included studies are summarized in Table 2. As shown in Figure 4, 22 form 21 articles with a total of 1,027 AD patients and 1,949 healthy controls were included in serum $\mathrm{Zn}$ meta-analysis. The patient sample sizes ranged from 5 (Kapaki et al., 1989) to 205 (Rembach et al., 2014) and control sample sizes from 10 (Shore et al., 1984) to 753 (Rembach et al., 2014). The mean age of the patient groups was $>54$. The percentage of female AD patients ranged from 20\% (Kapaki et al., 1989) to $100 \%$ (Molaschi et al., 1996).

Of the 22 included studies, results are discordant. As shown in Table 2, 3 studies reported an increase of serum $\mathrm{Zn}$ in $\mathrm{AD}$ patients; 18 studies reported a decrease, but none of them showed 


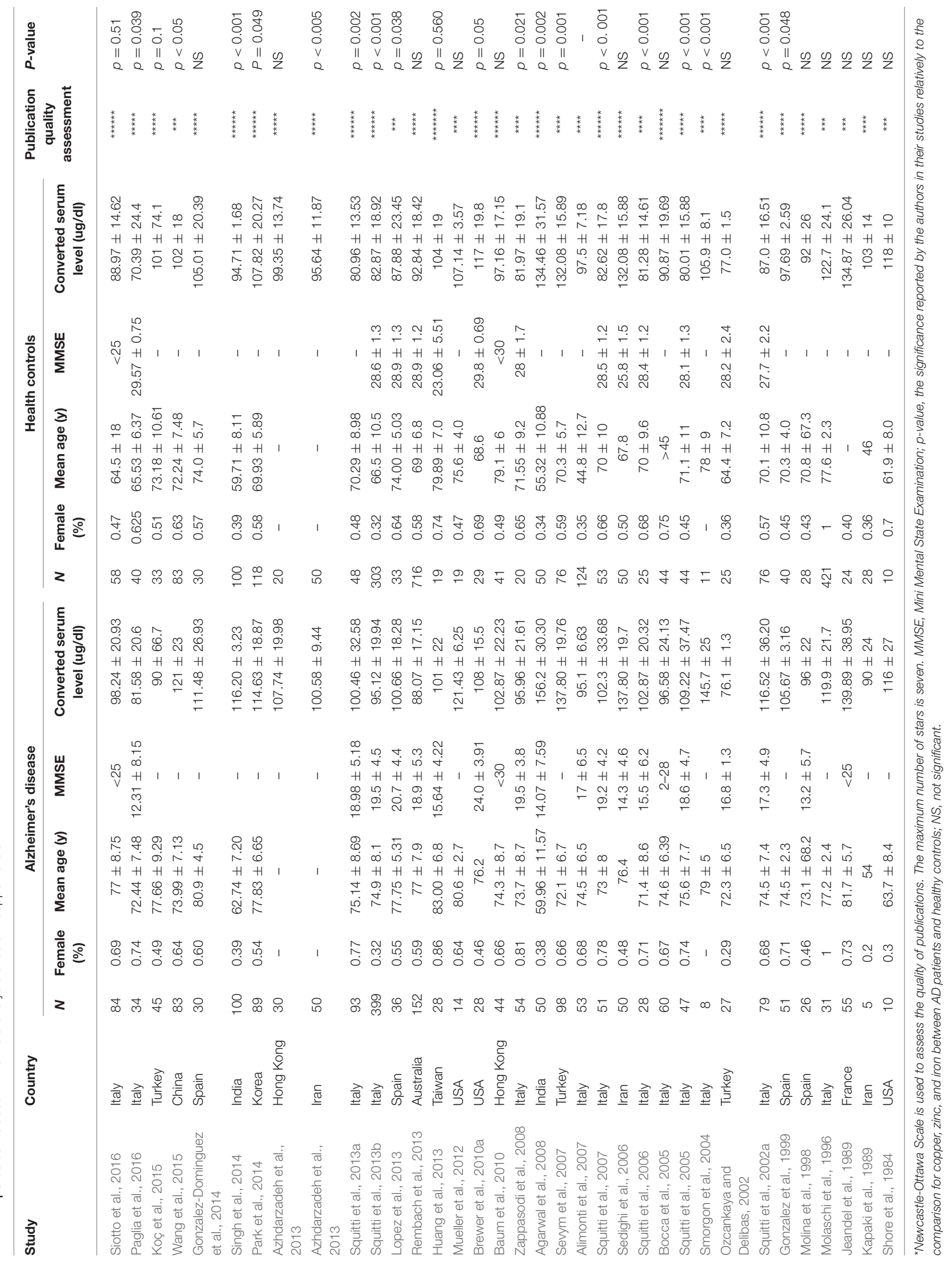




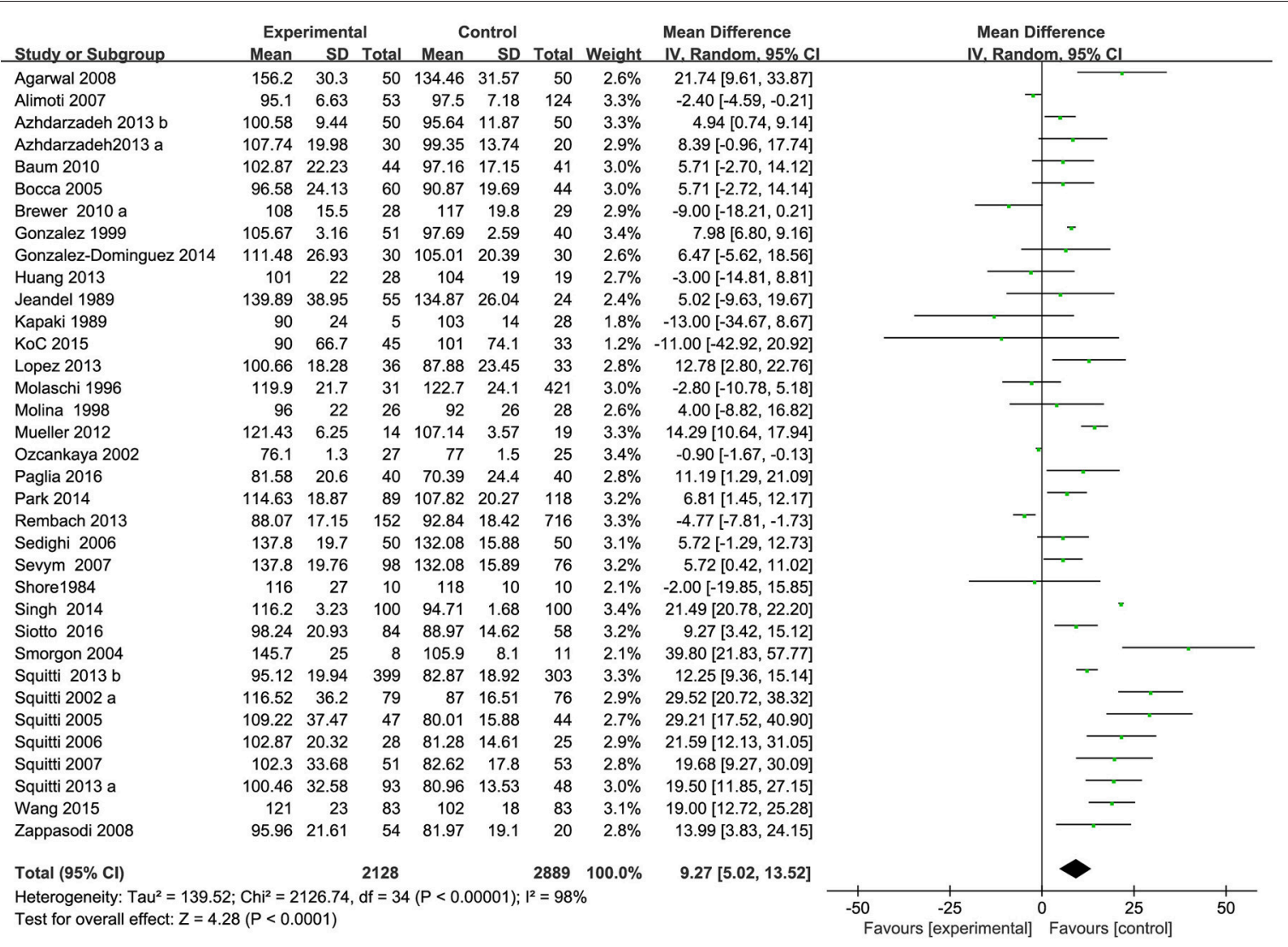

FIGURE 2 | Forest plots for serum Cu levels in AD and healthy controls in included studies.

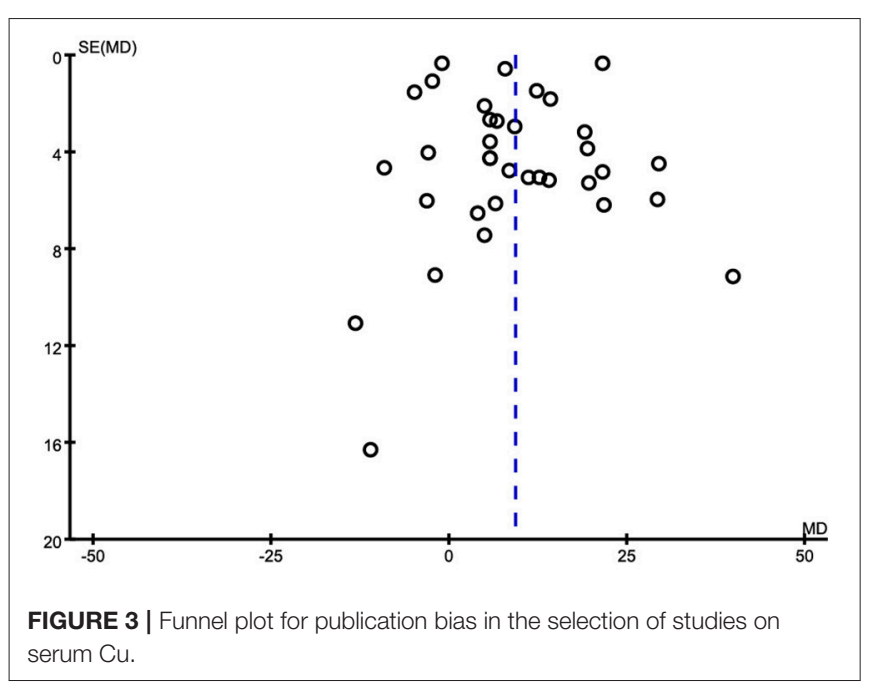

a significant difference of serum $\mathrm{Zn}$ between $\mathrm{AD}$ patients and controls; one of the studies reported that no significantly change of serum $\mathrm{Zn}$ was observed between $\mathrm{AD}$ patients and controls. Combined analysis of the relationship between the serum zinc level and $\mathrm{AD}$ was shown in a forest plot (Figure 2). The metaanalysis demonstrated $\mathrm{Zn}$ levels were significantly lower in $\mathrm{AD}$ patients than controls $[\mathrm{MD}=-6.12,95 \% \mathrm{CI}(-9.55,-2.69)$; $p=0.0005]$. As a high heterogeneity between the included studies was observed $\left(\mathrm{I}^{2}=96 \%\right)$, we ran a sensitivity analysis and found that the $\mathrm{I}^{2}=92 \%$ after excluding the study of Alimonti et al. (2007) and Gonzalez et al. (1999). After the exclusion, significant differences of the serum $\mathrm{Zn}$ were observed between $\mathrm{AD}$ patients and normal controls $[\mathrm{MD}=-7.80,95 \% \mathrm{CI}(-11.61$, $-3.99) ; p<0.0001$ ]. Publication bias was assessed graphically using a funnel plot (Figure 5). Moreover, we also ran a subgroup analysis for the percentage of women $(p=0.11)$, the mean age $(p=0.55)$, and country $\left(p=0.05, \mathrm{I}^{2}=61.11 \%\right)$ as a possible confounder, which revealed no variation of the serum $\mathrm{Zn}$ strictly associated with them.

\section{Studies on Fe in Serum}

Characteristics of the 25 included studies are summarized in Table 3. As shown in Figure 6, 25 form 24 articles with a total of 1,379 $\mathrm{AD}$ patients and 1,664 healthy controls were included in serum Fe meta-analysis. The patient sample sizes are ranged from 14 (Mueller et al., 2012) to 116 (Crespo et al., 2014) and control sample size from 13 (Thome et al., 1996) to 421 (Molaschi et al., 1996). The mean age of the patient groups was $>62.74$. The percentage of female AD subjects ranged from 32\% (Ozcankaya and Delibas, 2002) to 100\% (Molaschi et al., 1996). 


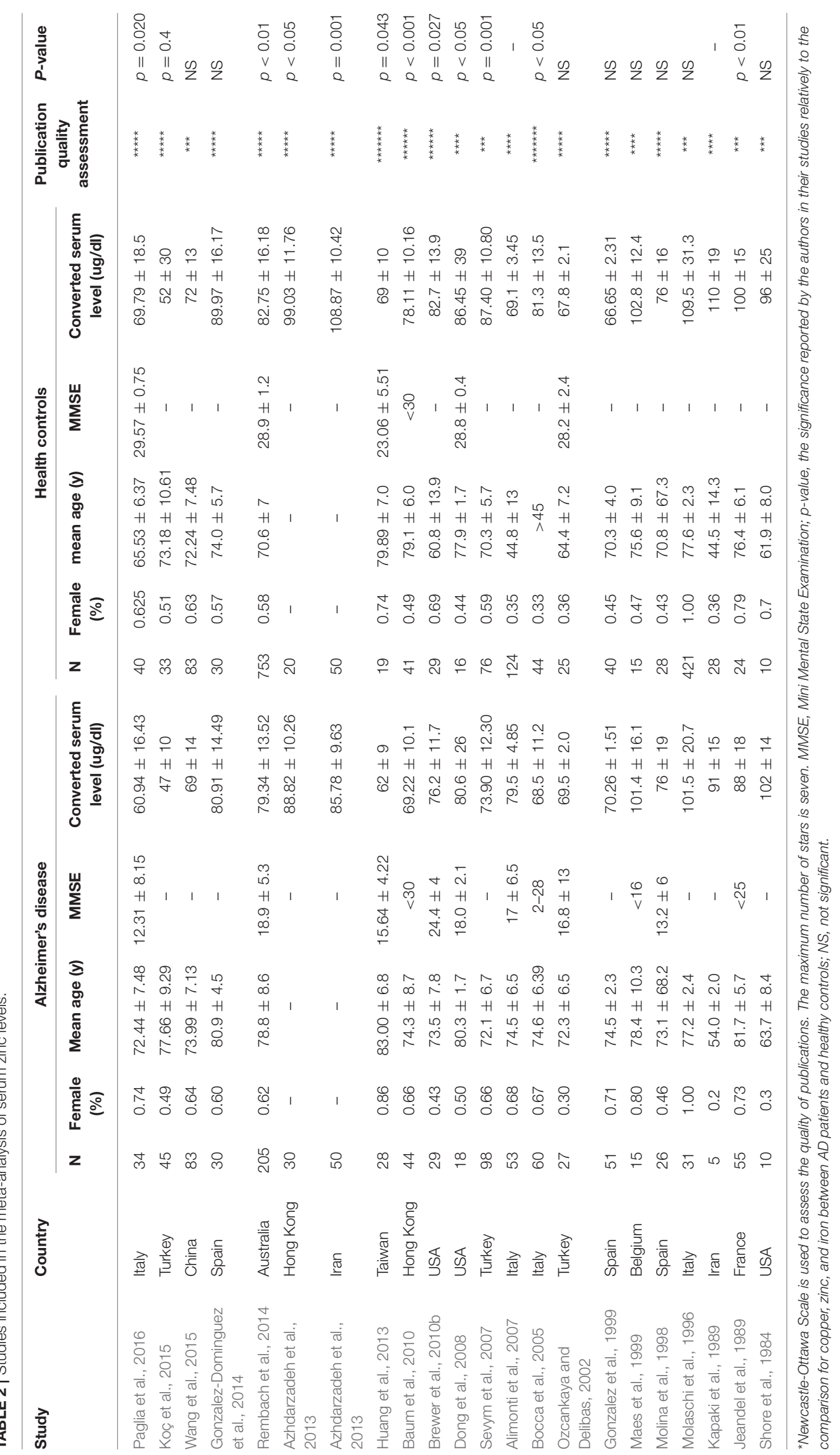




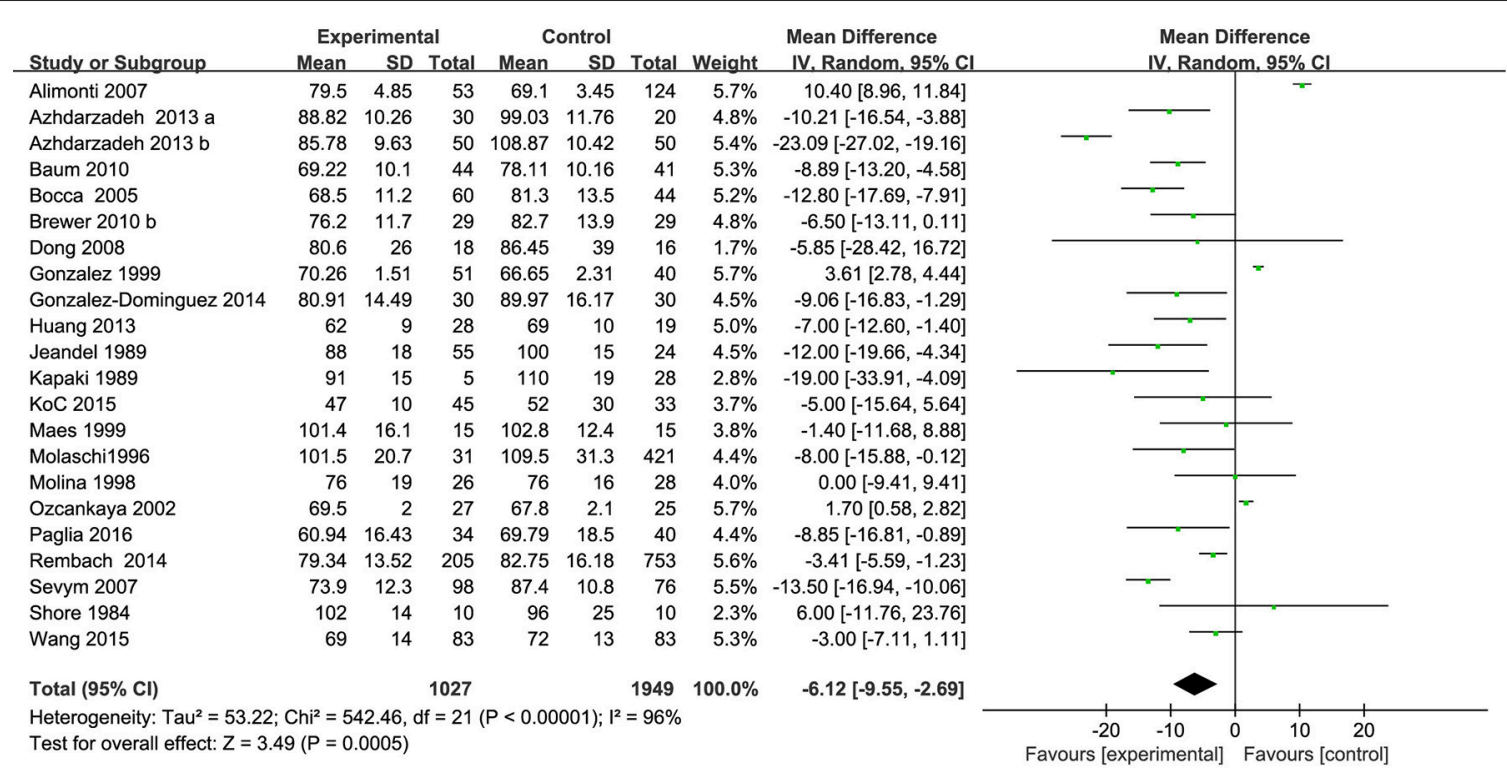

FIGURE 4 | Forest plots for serum Zn levels in AD and healthy controls in included studies.

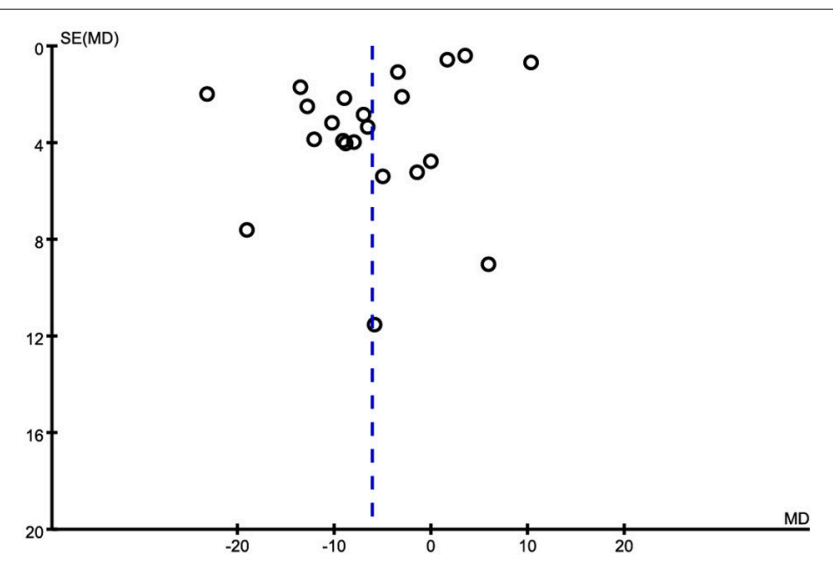

FIGURE 5 | Funnel plot for publication bias in the selection of studies on the serum Zn.

Of the 25 included studies, results are discordant, as shown in Table 3, 5 studies reported an increase of serum Fe levels in $\mathrm{AD}$ patients, but one of the studies reported a tiny increase. The other 20 studies reported a decrease of serum Fe levels in $\mathrm{AD}$ patients. Combined analysis of the relationship between the serum Fe level and AD was shown in a forest plot (Figure 6). The results indicated that on significant difference of Fe levels were observed between $\mathrm{AD}$ patients and controls $[\mathrm{MD}=-7.60$, $95 \%$ CI $(-20.75,5.56) ; p=0.26]$. As a high heterogeneity between the included studies was observed $\left(\mathrm{I}^{2}=99 \%\right)$, we ran a sensitivity analysis and found that the $\mathrm{I}^{2}=93 \%$ after excluding the study of Alimonti et al. (2007) and Ozcankaya and Delibas (2002). After the exclusion, significant differences of the serum Fe were observed between $\mathrm{AD}$ patients and normal controls $[\mathrm{MD}=-13.01,95 \% \mathrm{CI}(-20.75,-5.27) ; p=0.001]$.
Publication bias was assessed graphically using a funnel plot (Figure 7). Moreover, we also ran a subgroup analysis for the percentage of women $\left(p<0.00001, \mathrm{I}^{2}=97.0 \%\right)$, the mean age $(p=0.31)$, and country $(p=0.68)$ as a possible confounder, which revealed no variation of the serum Fe strictly associated with them. From the above, we concluded that the variation of the serum $\mathrm{Fe}$ concentration found in some of the studies might be associated with the percentage of women of the subjects.

\section{DISCUSSION}

$\mathrm{AD}$ is the most common form of irreversible dementia, and is clinically characterized by the progressive memory problems. Abnormal homeostasis of trace metals is also observed in $\mathrm{AD}$ patients, especially the metabolism of $\mathrm{Cu}, \mathrm{Zn}$, and $\mathrm{Fe}$. The purpose of this meta-analysis was to evaluate the association between serum $\mathrm{Cu} / \mathrm{Zn} / \mathrm{Fe}$ and $\mathrm{AD}$ risk. To do so, we performed a meta-analysis of selected case-control studies papers from 1975 to 2016 that enriched the literatures on these topics. We ran a meta-analysis for the serum $\mathrm{Cu} / \mathrm{Zn} / \mathrm{Fe}$ in $\mathrm{AD}$ patients and healthy controls in case-control studies.

\section{Serum Cu Levels Are Positively and Serum Zn Levels Are Negatively Associated with AD}

Senile plaques are the typical pathology change of $\mathrm{AD}$ brains, which are composed of variety of components, including extracellular deposits of $A \beta$, lipids, heavy metal, and so on. Based on this evidence, $A \beta$ plaques are sought to be a therapeutic targets of $\mathrm{AD}$. In the past decades, several different classes of drugs were generated to prohibit $A \beta$ plaques formation. But finally, many of them failed to improve the cognition of $\mathrm{AD}$ patients in the phase III clinical trials, suggesting that inhibition 


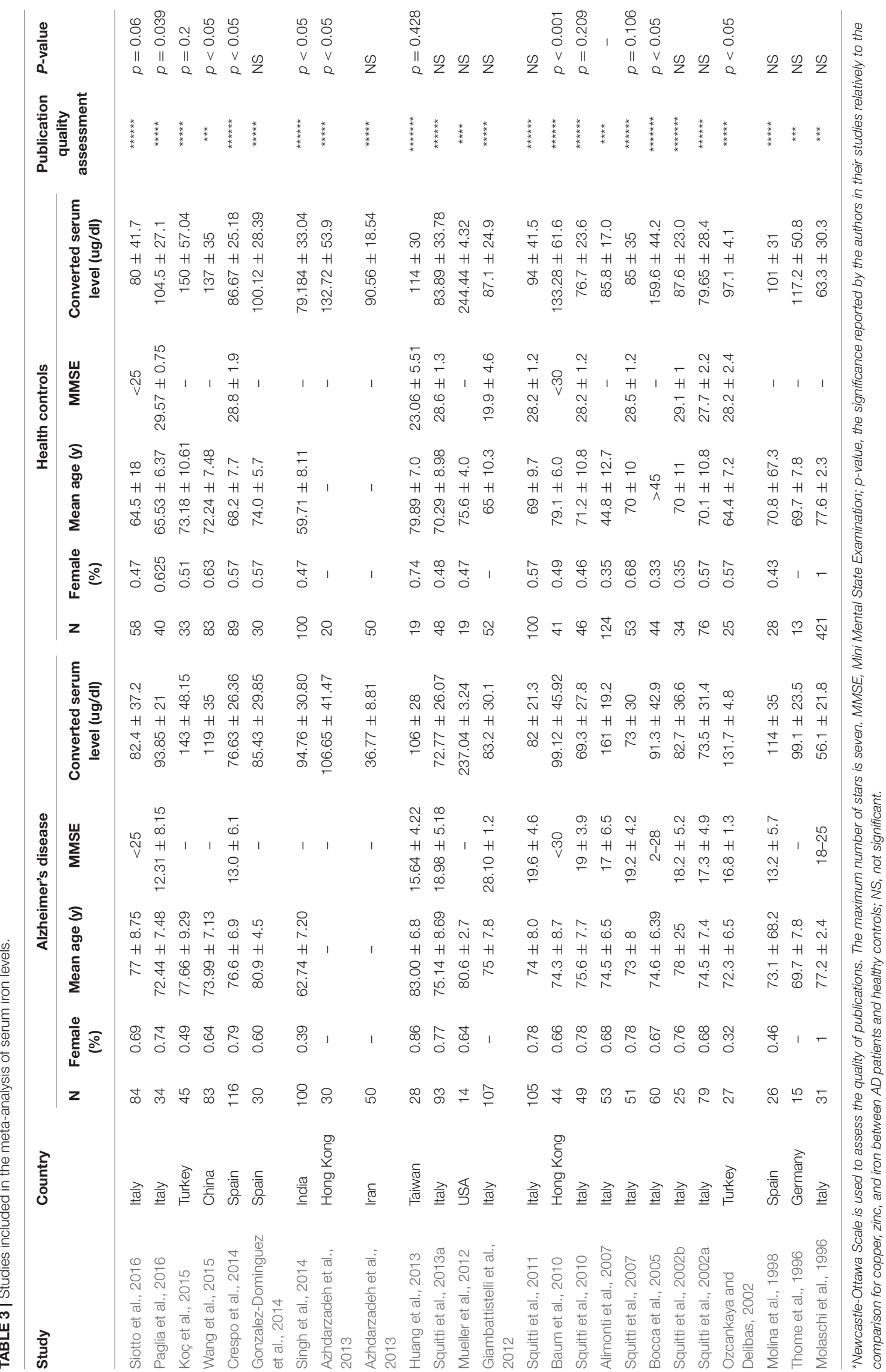




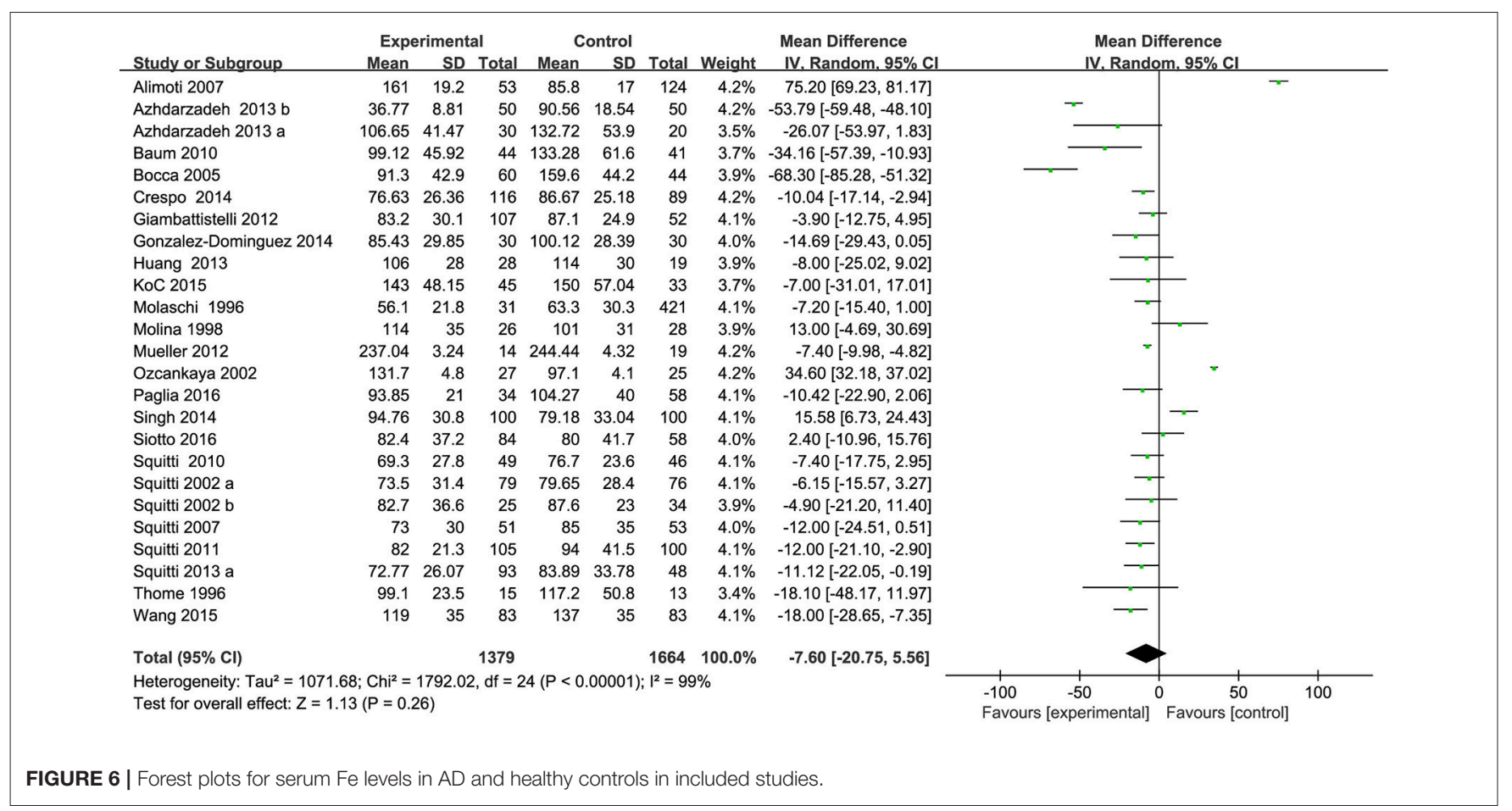

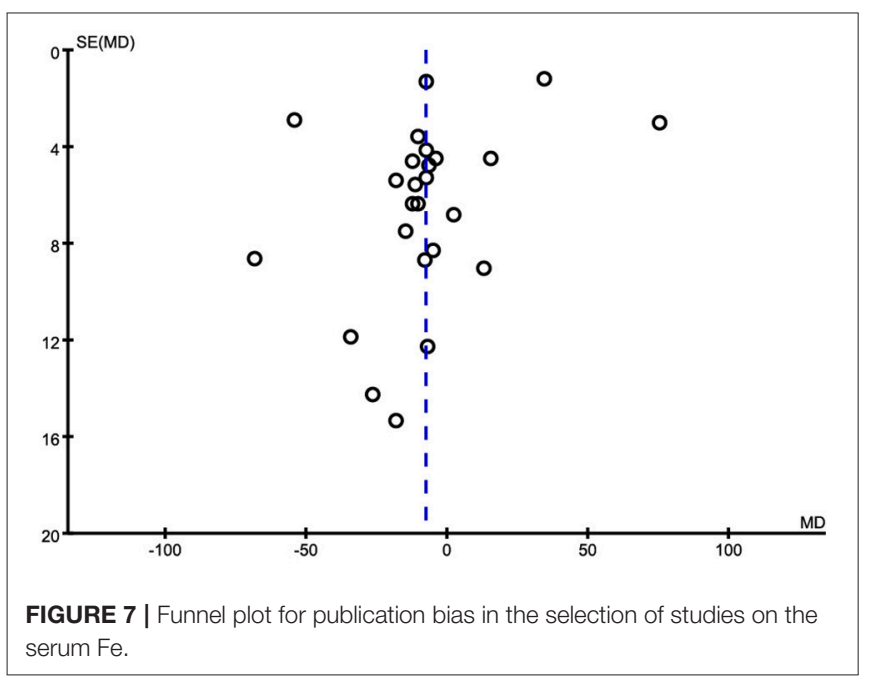

of senile plaques formation by using $\gamma$-secretase inhibitors or $A \beta$ antibodies are not effective ways to dealing with AD. Another approach to reduce the toxicity of $A \beta$ aggregation is to modulate the homeostasis of heavy metals, especially $\mathrm{Cu}, \mathrm{Zn}$, and $\mathrm{Fe}$. Potential association between these metal ions and $\mathrm{AD}$ were showed. Dysfunction of metal ions could be an indicator for $\mathrm{AD}$ diagnosis and a good target for AD therapy.

In vivo, $\mathrm{Cu}$ was absorbed in the small intestine by amino acid transporters, and then was transported into the blood in two forms, ceruloplasmin (Cp) and non-Cp Cu. Non-Cp $\mathrm{Cu}$ is also called "free copper" which is more freely available for cellular uses. The study form Dr. Rosanna Squitti et al. has proved that "free Cu" level is elevated in $\mathrm{AD}$ patients when compared with age-matched controls (Squitti et al., 2005). Their recent metaanalysis study revealed that the increase in total $\mathrm{Cu}$ observed in $\mathrm{AD}$ patients can be attributed to the increase in "free $\mathrm{Cu}$ " in serum (Squitti et al., 2014), suggesting that the total Cu level in serum can be used to evaluate the bioavailable $\mathrm{Cu}$ in serum.

The conclusion of our meta-analysis revealed a significant increase of serum $\mathrm{Cu}$ and a decrease of serum $\mathrm{Zn}$ in $\mathrm{AD}$ patients than in healthy controls. In this study, we also ran a subgroup analysis for the possible confounders, including mean age of the subjects, percentage of women and the country. Differences of the serum $\mathrm{Cu}$ and $\mathrm{Zn}$ are unlikely to be affected by these factors, which suggesting that the overall results of our metaanalysis on $\mathrm{Cu} / \mathrm{Zn}$ level were statistically robust. Focusing on the relationship between $\mathrm{Cu}$ and $\mathrm{Zn}$, we found that these metal ions are competed with each other. They shared binding partners, such as melallothionein (MT), copper/zinc-superoxide dismutase 1 (SOD1), and A $\beta$. Zn-binding MT and the other Zn-binding proteins are function as a buffer system to buffer serum $\mathrm{Cu}$, and then maintain the $\mathrm{Cu}$ homeostasis. Except for forming $\mathrm{Zn}$ binding proteins, $\mathrm{Zn}$ also mediated cell signaling pathways via modulating the activity of transcription factors, including Sp1, MTF-1, EGR1, GR, RAR, Ikaros, and Churchill. In vitro, MTs can bind more than seven equivalents of metal ions (Meloni et al., 2009; Sutherland et al., 2012). They adjust the balance of heavy metal ions, especially $\mathrm{Cu}$ and $\mathrm{Zn}$. Generally speaking, when $\mathrm{Cu}^{+}$levels is increased in cells, they competed the metal binding sites in MT and other metal binding proteins with $\mathrm{Zn}^{2+}$, thus increase free $\mathrm{Zn}^{2+}$ in cells. Free $\mathrm{Zn}^{2+}$ then bind with $\mathrm{Zn}$-sensitive transcription factors (MTF-1), to activate the expression of MTs. 
Then the elevated MTs bind with $\mathrm{Cu}^{+}$and take $\mathrm{Cu}^{+}$out into the stool as intestinal cells are shed.

When $\mathrm{Cu}$ level is rising for a short term, the metal buffer system composed of MTs and metal-binding proteins can buffer the instantaneous increase of $\mathrm{Cu}^{+}$effectively. But when $\mathrm{Cu}$ level is rising for a long term, cells will change their status to fit the $\mathrm{Cu}$ disorder. In this situation, metal binding protein, such as MTs (Hidalgo et al., 2006) and Cp (Park et al., 2014) are up-regulated to minimize the $\mathrm{Cu}$ toxicity. If the $\mathrm{Cu}$ level rise is beyond the body short-term buffer capacity (competing metal binding site in metalloproteins with $\mathrm{Zn}$ ) and long-term buffer capacity (increasing metalloprotein expression), the $\mathrm{Cu}$ level is irreversible increasing in general circulation. These $\mathrm{Cu}$ could loosely bind to low-molecular-weight proteins or peptides, and cross the blood brain barrier to reach the brain. Then the overloaded $\mathrm{Cu}$ will enhance toxicity of $\mathrm{A} \beta$ via inducing ROS production in $A \beta$ aggregation (Mayes et al., 2014). To validate the effects of $\mathrm{Cp} \mathrm{Cu}$ and non- $\mathrm{Cp} \mathrm{Cu}$ on $\mathrm{AD}$ progression, Dr. Rosanna Squitti and their collegues studied the correlationship of serum $\mathrm{Cu}$ in $\mathrm{AD}$ and $\mathrm{A} \beta$ concentration in cerebrospinal fluid (CSF). They found that "free $\mathrm{Cu}$ " in serum is negatively associated with $A \beta$ in the CSF sustained the direct interaction between $\mathrm{Cu}^{2+}$ and $\mathrm{A} \beta$ (Squitti et al., 2006). Although, our meta-analysis results consistent with many of others' that serum $\mathrm{Cu}$ level is positively (Bucossi et al., 2011; Squitti et al., 2014; Kisler et al., 2017), and serum Zn level is negatively (Ventriglia et al., 2015; Wang et al., 2015) associated with AD risk, the causal relationship between $\mathrm{Cu} / \mathrm{Zn}$ level and $\mathrm{AD}$ is still in debate. Fortunately, the epidemiologic data from using copper plumbing and $\mathrm{AD}$, and the success application of $\mathrm{Cu}$ chelators and $\mathrm{Zn}$ reagents in mouse model of $\mathrm{AD}$ provide strong evidences that $\mathrm{AD}$ is a heavy metal overloading disease.

\section{Serum Fe Was Significantly Lower in AD Patients}

$\mathrm{Fe}$ is another essential metal that plays a key role in $\mathrm{AD}$ pathophysiology. Similar as $\mathrm{Cu}, \mathrm{Fe}$ has a high binding affinity to $A \beta$ peptides, and it can provoke oxidative stress through the Fenton's reaction (Sayre et al., 2001). The postmortem analysis indicated that $\mathrm{Fe}$ co-localized with $\mathrm{A} \beta$ in senile plaques in $\mathrm{AD}$ brains (Jiang et al., 2009; Moreira et al., 2010). Moreover, the Fe-responsive $5^{\prime}$-UTR region in A $\beta$ PP promoter is the potential target for $\mathrm{Fe}$ ions. The study from Crespo et al. indicated that transferrin and ferritin are significant decreased in the serum of $\mathrm{AD}$ patients than in controls. These two proteins are the key proteins that control the transportation and the storage of $\mathrm{Fe}$ in the body. It is also reported that the gene variation of transferrin and ferritin are associated with AD (Giambattistelli et al., 2012). According to these evidences, it is reasonable to speculated that $\mathrm{Fe}$ homeostasis may be associated with $\mathrm{AD}$ progression. The results of our meta-analysis revealed that no significant changes of serum Fe concentration were observed between $\mathrm{AD}$ patients and healthy controls, pointing out a high heterogeneity. But after the sensitivity analysis, we found that the studies of Alimonti et al. (2007) and Ozcankaya and Delibas (2002) have a big impact on the overall result. After excluding these two studies, the heterogeneity was reduced to $93.0 \%$ and serum Fe was significantly lower in $\mathrm{AD}$ patients $(\mathrm{MD}=-15.144 ; p=0.002)$ which is consistent with previous meta-analysis resulted from Tao et al. (2014). We excluded the studies by Alimonti et al. (2007) because the age of some controls was $<45$ years. The studies of Ozcankaya et al. showed that low levels of melatonin are associated with the development of $\mathrm{AD}$, especially when accompanied with an increased Fe levels, so that might be the source of the heterogeneity of this study. Although the present meta-analysis showed that the serum Fe level was significantly lower in $\mathrm{AD}$ patients after excluding two studies with high heterogeneity, more studies are needed reveal the association of serum Fe and AD.

\section{Limitations}

The present study still had some potential limitations that warrant mention. First, significant heterogeneity existed in the meta-analysis of the serum $\mathrm{Cu} / \mathrm{Zn} / \mathrm{Fe}$ in $\mathrm{AD}$ patients and healthy controls. The heterogeneity of the involved case-control studies are partially associated with the confounders, therefore, heterogeneity was still a problem that may affect the precision of the overall results in this meta-analysis. Second, the casecontrol studies means that the findings are might be affected by varying levels of bias owing to the quality evaluation of literature. Although the involved studies were reasonably homogeneous in most areas, there were some between-study variations that may have effects on the outcomes and thus the results of our meta-analysis. Third, we must acknowledge that the present case-control studies meta-analyses included limited number of studies; hence, the results must be clearly interpreted with some degree of caution. Fourth, only a few studies involving North America, Oceania were included in this meta-analysis. More studies are needed from other countries to evaluate the association between the serum metal levels and AD.

\section{CONCLUSION}

In conclusion, from our current study, we provide statistical support that serum $\mathrm{Cu}$ was significantly increased and serum $\mathrm{Zn} / \mathrm{Fe}$ was significantly decreased in $\mathrm{AD}$ patients. For serum $\mathrm{Cu}$, the present case-control studies meta-analysis along with other four meta-analyses reached the same conclusion (Citron, 2010; Schrag et al., 2013; Squitti et al., 2014; Wang et al., 2015). For serum $\mathrm{Zn}$, the results of our meta-analysis are consistent with other two meta-analyses (Ventriglia et al., 2015; Wang et al., 2015). For serum Fe, the results of the present meta-analysis are consistent with other two meta-analyses(Tao et al., 2014; Wang et al., 2015), indicating that serum Fe was significantly lower in $\mathrm{AD}$ patients than in healthy controls after excluding the studies of Alimonti et al. (2007) and Ozcankaya and Delibas (2002), but notably, this conclusion was not robust and needs further studies.

\section{AUTHOR CONTRIBUTIONS}

$\mathrm{PZ}$ and ZW designed the study. DL and WZ performed the experiments and data analysis. $\mathrm{PZ}$ and $\mathrm{WZ}$ wrote the paper. 


\section{FUNDING}

This work was supported in part or in whole by the National Natural Sciences Foundation of China (31301108) and (31401215), the Fundamental Research Funds for Central Public Welfare Research Institutes of China (N130520002, N141008001/7, N130320001), Natural Science Foundation of Liaoning Province (2015020401).

\section{REFERENCES}

Agarwal, R., Kushwaha, S. S., Tripathi, C. B., Singh, N., and Chhillar, N. (2008). Serum copper in Alzheimer's disease and vascular dementia. Indian J. Clin. Biochem. 23, 369-374. doi: 10.1007/s12291-008-0081-8

Alimonti, A., Ristori, G., Giubilei, F., Stazi, M. A., Pino, A., Visconti, A., et al. (2007). Serum chemical elements and oxidative status in Alzheimer's disease, Parkinson disease and multiple sclerosis. Neurotoxicology 28, 450-456. doi: 10.1016/j.neuro.2006.12.001

Azhdarzadeh, M., Noroozian, M., Aghaverdi, H., Akbari, S. M., Baum, L., and Mahmoudi, M. (2013). Serum multivalent cationic pattern: speculation on the efficient approach for detection of Alzheimer's disease. Sci. Rep. 3:2782. doi: $10.1038 /$ srep02782

Baum, L., Chan, I. H., Cheung, S. K., Goggins, W. B., Mok, V., Lam, L., et al. (2010). Serum zinc is decreased in Alzheimer's disease and serum arsenic correlates positively with cognitive ability. Biometals 23, 173-179. doi: 10.1007/s10534-009-9277-5

Bocca, B., Forte, G., Petrucci, F., Pino, A., Marchione, F., Bomboi, G., et al. (2005). Monitoring of chemical elements and oxidative damage in patients affected by Alzheimer's disease. Ann. Ist. Super. Sanita 41, 197-203.

Brewer, G. J. (2012). Copper excess, zinc deficiency, and cognition loss in Alzheimer's disease. Biofactors 38, 107-113. doi: 10.1002/biof.1005

Brewer, G. J., Kanzer, S. H., Zimmerman, E. A., Celmins, D. F., Heckman, S. M., and Dick, R. (2010a). Copper and ceruloplasmin abnormalities in Alzheimer's disease. Am. J. Alzheimers. Dis. Other Demen. 25, 490-497. doi: $10.1177 / 1533317510375083$

Brewer, G. J., Kanzer, S. H., Zimmerman, E. A., Molho, E. S., Celmins, D. F., Heckman, S. M., et al. (2010b). Subclinical zinc deficiency in Alzheimer's disease and Parkinson's disease. Am. J. Alzheimers. Dis. Other Demen. 25, 572-575. doi: 10.1177/1533317510382283

Bucossi, S., Ventriglia, M., Panetta, V., Salustri, C., Pasqualetti, P., Mariani, S., et al. (2011). Copper in Alzheimer's disease: a meta-analysis of serum,plasma, and cerebrospinal fluid studies. J. Alzheimers. Dis. 24, 175-185. doi: 10.3233/JAD-2010-101473

Buendia, I., Parada, E., Navarro, E., Leon, R., Negredo, P., Egea, J., et al. (2016). Subthreshold concentrations of melatonin and galantamine improves pathological AD-hallmarks in hippocampal organotypic cultures. Mol. Neurobiol. 53, 3338-3348. doi: 10.1007/s12035-015-9272-5

Cheignon, C., Faller, P., Testemale, D., Hureau, C., and Collin, F. (2016). Metal-catalyzed oxidation of Abeta and the resulting reorganization of $\mathrm{Cu}$ binding sites promote ROS production. Metallomics 8, 1081-1089. doi: 10.1039/C6MT00150E

Citron, M. (2010). Alzheimer's disease: strategies for disease modification. Nat. Rev. Drug Discov. 9, 387-398. doi: 10.1038/nrd2896

Coory, M. D. (2010). Comment on: heterogeneity in meta-analysis should be expected and appropriately quantified. Int. J. Epidemiol. 39, 932; author reply 933. doi: 10.1093/ije/dyp157

Crespo, A. C., Silva, B., Marques, L., Marcelino, E., Maruta, C., Costa, S., et al. (2014). Genetic and biochemical markers in patients with Alzheimer's disease support a concerted systemic iron homeostasis dysregulation. Neurobiol. Aging 35, 777-785. doi: 10.1016/j.neurobiolaging.2013.10.078

Dong, J., Robertson, J. D., Markesbery, W. R., and Lovell, M. A. (2008). Serum zinc in the progression of Alzheimer's disease. J. Alzheimers. Dis. 15, 443-450. doi: 10.3233/JAD-2008-15310

Exley, C. (2006). Aluminium and iron, but neither copper nor zinc, are key to the precipitation of beta-sheets of Abeta_\{42\} in senile plaque cores in Alzheimer's disease. J. Alzheimers. Dis. 10, 173-177. doi: 10.3233/JAD-2006-102-305

Giambattistelli, F., Bucossi, S., Salustri, C., Panetta, V., Mariani, S., Siotto, M., et al. (2012). Effects of hemochromatosis and transferrin gene mutations on

iron dyshomeostasis, liver dysfunction and on the risk of Alzheimer's disease. Neurobiol. Aging 33, 1633-1641. doi: 10.1016/j.neurobiolaging.2011.03.005

Gonzalez, C., Martin, T., Cacho, J., Brenas, M. T., Arroyo, T., Garcia-Berrocal, B., et al. (1999). Serum zinc, copper, insulin and lipids in Alzheimer's disease epsilon 4 apolipoprotein E allele carriers. Eur. J. Clin. Invest. 29, 637-642. doi: 10.1046/j.1365-2362.1999.00471.x

Gonzalez-Dominguez, R., Garcia-Barrera, T., and Gomez-Ariza, J. L. (2014). Characterization of metal profiles in serum during the progression of Alzheimer's disease. Metallomics 6, 292-300. doi: 10.1039/C3MT00301A

Greenough, M. A., Ramirez Munoz, A., Bush, A. I., and Opazo, C. M. (2016). Metallo-pathways to Alzheimer's disease: lessons from genetic disorders of copper trafficking. Metallomics 8, 831-839. doi: 10.1039/C6MT00095A

Guo, J. P., Pan, J. X., Xiong, L., Xia, W. F., Cui, S., and Xiong, W. C. (2015). Iron chelation inhibits osteoclastic differentiation in vitro and in Tg2576 mouse model of Alzheimer's disease. PLoS ONE 10:e0139395. doi: 10.1371/journal.pone.0139395

Hidalgo, J., Penkowa, M., Espejo, C., Martinez-Caceres, E. M., Carrasco, J., Quintana, A., et al. (2006). Expression of metallothionein-I, -II, and -III in Alzheimer disease and animal models of neuroinflammation. Exp. Biol. Med. 231, 1450-1458. doi: 10.1177/153537020623100902

Higgins, J. P. T., and Green, S. (2009). Cochrane Handbook for Systematic Reviews of Interventions Version 5.1.0 [updated March 2011].

Huang, C. W., Wang, S. J., Wu, S. J., Yang, C. C., Huang, M. W., Lin, C. H., et al. (2013). Potential blood biomarker for disease severity in the Taiwanese population with Alzheimer's disease. Am. J. Alzheimers. Dis. Other Demen. 28, 75-83. doi: 10.1177/1533317512467674

James, S. A., Churches, Q. I., de Jonge, M. D., Birchall, I. E., Streltsov, V., McColl, G., et al. (2017). Iron, copper, and zinc concentration in A $\beta$ plaques in the APP/PS1 mouse model of Alzheimer's disease correlates with metal levels in the surrounding neuropil. ACS Chem. Neurosci. 8, 629-637. doi: 10.1021/acschemneuro.6b00362

Jeandel, C., Nicolas, M. B., Dubois, F., Nabet-Belleville, F., Penin, F., and Cuny, G. (1989). Lipid peroxidation and free radical scavengers in Alzheimer's disease. Gerontology 35, 275-282. doi: 10.1159/000213037

Jiang, D., Li, X., Williams, R., Patel, S., Men, L., Wang, Y., et al. (2009). Ternary complexes of iron, amyloid-beta, and nitrilotriacetic acid: binding affinities, redox properties, and relevance to iron-induced oxidative stress in Alzheimer's disease. Biochemistry 48, 7939-7947. doi: 10.1021/bi900907a

Kapaki, E., Segditsa, J., and Papageorgiou, C. (1989). Zinc, copper and magnesium concentration in serum and CSF of patients with neurological disorders. Acta Neurol. Scand. 79, 373-378. doi: 10.1111/j.1600-0404.1989.tb03803.x

Kisler, K., Nelson, A. R., Montagne, A., and Zlokovic, B. V. (2017). Cerebral blood flow regulation and neurovascular dysfunction in Alzheimer disease. Nat. Rev. Neurosci. 18, 419-434. doi: 10.1038/nrn.2017.48

Koç, E. R., Ilhan, A., AytüRk, Z., Acar, B., GüRler, M., Altuntaş, A., et al. (2015). A comparison of hair and serum trace elements in patients with Alzheimer disease and healthy participants. Turkish J. Med. Sci. 45, 1034-1039. doi: 10.3906/sag-1407-67

Kreutzer, A. G., Yoo, S., Spencer, R. K., and Nowick, J. S. (2017). Stabilization, assembly, and toxicity of trimers derived from abeta. J. Am. Chem. Soc. 139, 966-975. doi: 10.1021/jacs.6b11748

Kulikova, A. A., Makarov, A. A., and Kozin, S. A. (2015). The role of zinc ions and structural polymorphism of beta-amyloid in the Alzheimer's disease initiation. Mol. Biol. 49, 249-263. doi: 10.1134/S0026893315020065

Lopez, N., Tormo, C., De Blas, I., Llinares, I., and Alom, J. (2013). Oxidative stress in Alzheimer's disease and mild cognitive impairment with high sensitivity and specificity. J. Alzheimers. Dis. 33, 823-829. doi: 10.3233/jad-2012-121528

Maes, M., DeVos, N., Wauters, A., Demedts, P., Maurits, V. W., Neels, H., et al. (1999). Inflammatory markers in younger vs. elderly normal volunteers 
and in patients with Alzheimer's disease. J. Psychiatr. Res. 33, 397-405. doi: 10.1016/S0022-3956(99)00016-3

Mayes, J., Tinker-Mill, C., Kolosov, O., Zhang, H., Tabner, B. J., and Allsop, D. (2014). beta-amyloid fibrils in Alzheimer disease are not inert when bound to copper ions but can degrade hydrogen peroxide and generate reactive oxygen species. J. Biol. Chem. 289, 12052-12062. doi: 10.1074/jbc.M113.525212

McCord, M. C., and Aizenman, E. (2014). The role of intracellular zinc release in aging, oxidative stress, and Alzheimer's disease. Front. Aging Neurosci. 6:77. doi: 10.3389/fnagi.2014.00077

Meloni, G., Polanski, T., Braun, O., and Vasak, M. (2009). Effects of $\mathrm{Zn}^{(2+)}, \mathrm{Ca}^{(2+)}$, and $\mathrm{Mg}^{(2+)}$ on the structure of $\mathrm{Zn}(7)$ metallothionein-3: evidence for an additional zinc binding site. Biochemistry 48, 5700-5707. doi: 10.1021/bi900366p

Mezentsev, Y. V., Medvedev, A. E., Kechko, O. I., Makarov, A. A., Ivanov, A. S., Mantsyzov, A. B., et al. (2016). Zinc-induced heterodimer formation between metal-binding domains of intact and naturally modified amyloid-beta species: implication to amyloid seeding in Alzheimer's disease? J. Biomol. Struct. Dyn. 34, 2317-2326. doi: 10.1080/07391102.2015.1113890

Moher, D., Liberati, A., Tetzlaff, J., and Altman, D. G. (2010). Preferred reporting items for systematic reviews and meta-analyses: the PRISMA statement. Int. J. Surg. 8, 336-341. doi: 10.1016/j.ijsu.2010.02.007

Molaschi, M., Ponzetto, M., Bertacna, B., Berrino, E., and Ferrario, E. (1996). Determination of selected trace elements in patients affected by dementia. Arch. Gerontol. Geriatr. 22(Suppl. 1), 39-42. doi: 10.1016/0167-4943(96) 86910-X

Molina, J. A., Jimenez-Jimenez, F. J., Aguilar, M. V., Meseguer, I., Mateos-Vega, C. J., Gonzalez-Munoz, M. J., et al. (1998). Cerebrospinal fluid levels of transition metals in patients with Alzheimer's disease. J. Neural. Transm. 105, 479-488. doi: $10.1007 / \mathrm{s} 007020050071$

Moreira, P. I., Sayre, L. M., Zhu, X., Nunomura, A., Smith, M. A., and Perry, G. (2010). Detection and localization of markers of oxidative stress by in situ methods: application in the study of Alzheimer disease. Methods Mol. Biol. 610, 419-434. doi: 10.1007/978-1-60327-029-8_25

Mueller, C., Schrag, M., Crofton, A., Stolte, J., Muckenthaler, M. U., Magaki, S., et al. (2012). Altered serum iron and copper homeostasis predicts cognitive decline in mild cognitive impairment. J. Alzheimers. Dis. 29, 341-350. doi: 10.3233/jad-2011-111841

Ozcankaya, R., and Delibas, N. (2002). Malondialdehyde, superoxide dismutase, melatonin, iron, copper, and zinc blood concentrations in patients with Alzheimer disease: cross-sectional study. Croat. Med. J. 43, 28-32.

Paglia, G., Miedico, O., Cristofano, A., Vitale, M., Angiolillo, A., Chiaravalle, A. E., et al. (2016). Distinctive pattern of serum elements during the progression of Alzheimer's disease. Sci. Rep. 6:22769. doi: 10.1038/srep22769

Pal, A., Siotto, M., Prasad, R., and Squitti, R. (2015). Towards a unified vision of copper involvement in Alzheimer's disease: a review connecting basic, experimental, and clinical research. J. Alzheimers. Dis. 44, 343-354. doi: 10.3233/JAD-141194

Park, J. H., Lee, D. W., and Park, K. S. (2014). Elevated serum copper and ceruloplasmin levels in Alzheimer's disease. Asia Pac. Psychiatry 6, 38-45. doi: 10.1111/appy.12077

Paulsen, J. S., Salmon, D. P., Thal, L. J., Romero, R., Weisstein-Jenkins, C., Galasko, D., et al. (2000). Incidence of and risk factors for hallucinations and delusions in patients with probable AD. Neurology 54, 1965-1971. doi: 10.1212/WNL.54.10.1965

Peters, D. G., Connor, J. R., and Meadowcroft, M. D. (2015). The relationship between iron dyshomeostasis and amyloidogenesis in Alzheimer's disease: two sides of the same coin. Neurobiol. Dis. 81, 49-65. doi: 10.1016/j.nbd.2015.08.007

Rembach, A., Doecke, J. D., Roberts, B. R., Watt, A. D., Faux, N. G., Volitakis, I., et al. (2013). Longitudinal analysis of serum copper and ceruloplasmin in Alzheimer's disease. J. Alzheimers. Dis. 34, 171-182. doi: 10.3233/jad121474

Rembach, A., Hare, D. J., Doecke, J. D., Burnham, S. C., Volitakis, I., Fowler, C. J., et al. (2014). Decreased serum zinc is an effect of ageing and not Alzheimer's disease. Metallomics 6, 1216-1219. doi: 10.1039/C4MT00060A

Sands, S. A., Leung-Toung, R., Wang, Y., Connelly, J., and LeVine, S. M. (2016). Enhanced histochemical detection of iron in paraffin sections of mouse central nervous system tissue: application in the APP/PS1 mouse model of Alzheimer's disease. ASN Neuro 8:1759091416670978. doi: 10.1177/1759091416670978
Sayre, L. M., Smith, M. A., and Perry, G. (2001). Chemistry and biochemistry of oxidative stress in neurodegenerative disease. Curr. Med. Chem. 8, 721-738. doi: 10.2174/0929867013372922

Schrag, M., Mueller, C., Zabel, M., Crofton, A., Kirsch, W. M., Ghribi, O., et al. (2013). Oxidative stress in blood in Alzheimer's disease and mild cognitive impairment: a meta-analysis. Neurobiol. Dis. 59, 100-110. doi: 10.1016/j.nbd.2013.07.005

Sedighi, B., Shafa, M., and Shariati, M. (2006). A study of serum copper and ceruloplasmin in Alzheimer's disease in Kerman, Iran. Neurol Asia 11, 107-109. Available online at: http://www.neurology-asia.org/articles/20062_107.pdf

Sepulcre, J., Schultz, A. P., Sabuncu, M., Gomez-Isla, T., Chhatwal, J., Becker, A., et al. (2016). In vivo tau, amyloid, and gray matter profiles in the aging brain. J. Neurosci. 36, 7364-7374. doi: 10.1523/JNEUROSCI.0639-16.2016

Sevym, S., Ünal, O., Tamer, L., Doğu, O., and Ozge, A. (2007). Can serum levels of copper and zinc distinguish Alzheimer's patients from normal subjects? J. Neurol. Sci. 24, 197-205. Available online at: http://jns.dergisi.org/text.php?\& id $=169$

Shore, D., Henkin, R. I., Nelson, N. R., Agarwal, R. P., and Wyatt, R. J. (1984). Hair and serum copper, zinc, calcium, and magnesium concentrations in Alzheimer-type dementia. J. Am. Geriatr. Soc. 32, 892-895. doi: 10.1111/j.1532-5415.1984.tb00889.x

Singh, N. K., Banerjee, B. D., Bala, K., Basu, M., and Chhillar, N. (2014). Polymorphism in cytochrome P450 2D6, glutathione S-transferases Pi 1 Genes, and organochlorine pesticides in Alzheimer disease: a case-control study in north indian population. J. Geriatr. Psychiatry Neurol. 27, 119-127. doi: $10.1177 / 0891988714522698$

Siotto, M., Simonelli, I., Pasqualetti, P., Mariani, S., Caprara, D., Bucossi, S., et al. (2016). Association between serum ceruloplasmin specific activity and risk of Alzheimer's disease. J. Alzheimers. Dis. 50, 1181-1189. doi: 10.3233/JAD-150611

Smorgon, C., Mari, E., Atti, A. R., Dalla Nora, E., Zamboni, P. F., Calzoni, F., et al. (2004). Trace elements and cognitive impairment: an elderly cohort study. Arch. Gerontol. Geriatr. Suppl. 9, 393-402. doi: 10.1016/j.archger.2004.04.050

Sparks, D. L., Friedland, R., Petanceska, S., Schreurs, B. G., Shi, J., Perry, G., et al. (2006). Trace copper levels in the drinking water, but not zinc or aluminum influence CNS Alzheimer-like pathology. J. Nutr. Health Aging 10, 247-254.

Squitti, R., Barbati, G., Rossi, L., Ventriglia, M., Dal Forno, G., Cesaretti, S., et al. (2006). Excess of nonceruloplasmin serum copper in AD correlates with MMSE, CSF [beta]-amyloid, and h-tau. Neurology 67, 76-82. doi: 10.1212/01.wnl.0000223343.82809.cf

Squitti, R., Ghidoni, R., Scrascia, F., Benussi, L., Panetta, V., Pasqualetti, P., et al. (2011). Free copper distinguishes mild cognitive impairment subjects from healthy elderly individuals. J. Alzheimers Dis. 23, 239-248. doi: 10.3233/JAD-2010-101098

Squitti, R., Lupoi, D., Pasqualetti, P., Dal Forno, G., Vernieri, F., Chiovenda, P., et al. (2002a). Elevation of serum copper levels in Alzheimer's disease. Neurology 59, 1153-1161. doi: 10.1212/WNL.59.8.1153

Squitti, R., Pasqualetti, P., Dal Forno, G., Moffa, F., Cassetta, E., Lupoi, D., et al. (2005). Excess of serum copper not related to ceruloplasmin in Alzheimer disease. Neurology 64, 1040-1046. doi: 10.1212/01.WNL.0000154531.79362.23

Squitti, R., Pasqualetti, P., Polimanti, R., Salustri, C., Moffa, F., Cassetta, E., et al. (2013a). Metal-score as a potential non-invasive diagnostic test for Alzheimer's disease. Curr. Alzheimer Res. 10, 191-198. doi: 10.2174/1567205011310020009

Squitti, R., Polimanti, R., Siotto, M., Bucossi, S., Ventriglia, M., Mariani, S., et al. (2013b). ATP7B variants as modulators of copper dyshomeostasis in Alzheimer's disease. Neuromol. Med. 15, 515-522. doi: 10.1007/s12017-013-8237-y

Squitti, R., Rossini, P. M., Cassetta, E., Moffa, F., Pasqualetti, P., Cortesi, M., et al. (2002b). d-penicillamine reduces serum oxidative stress in Alzheimer's disease patients. Eur. J. Clin. Invest. 32, 51-59. doi: 10.1046/j.1365-2362.2002.00933.x

Squitti, R., Salustri, C., Siotto, M., Ventriglia, M., Vernieri, F., Lupoi, D., et al. (2010). Ceruloplasmin/Transferrin ratio changes in Alzheimer's disease. Int. J. Alzheimers. Dis. 2011:231595. doi: 10.4061/2011/231595

Squitti, R., Simonelli, I., Ventriglia, M., Siotto, M., Pasqualetti, P., Rembach, A., et al. (2014). Meta-analysis of serum non-ceruloplasmin copper in Alzheimer's disease. J. Alzheimers. Dis. 38, 809-822. doi: 10.3233/JAD-131247

Squitti, R., Ventriglia, M., Barbati, G., Cassetta, E., Ferreri, F., Dal Forno, G., et al. (2007). 'Free' copper in serum of Alzheimer's disease patients 
correlates with markers of liver function. J. Neural Transm. 114, 1589-1594. doi: 10.1007/s00702-007-0777-6

Sutherland, D. E., Willans, M. J., and Stillman, M. J. (2012). Single domain metallothioneins: supermetalation of human MT 1a. J. Am. Chem. Soc. 134, 3290-3299. doi: 10.1021/ja211767m

Tao, Y., Wang, Y., Rogers, J. T., and Wang, F. (2014). Perturbed iron distribution in Alzheimer's disease serum, cerebrospinal fluid, and selected brain regions: a systematic review and meta-analysis. J. Alzheimers. Dis. 42, 679-690. doi: 10.3233/JAD-140396

Thome, J., Munch, G., Muller, R., Schinzel, R., Kornhuber, J., Blum-Degen, D., et al. (1996). Advanced glycation endproducts-associated parameters in the peripheral blood of patients with Alzheimer's disease. Life Sci. 59, 679-685. doi: 10.1016/0024-3205(96)00349-9

Tractenberg, R. E., Weiner, M. F., and Thal, L. J. (2002). Estimating the prevalence of agitation in community-dwelling persons with Alzheimer's disease. J. Neuropsychiatry Clin. Neurosci. 14, 11-18. doi: 10.1176/jnp. 14.1.11

Ventriglia, M., Brewer, G. J., Simonelli, I., Mariani, S., Siotto, M., Bucossi, S., et al. (2015). Zinc in Alzheimer's disease: a meta-analysis of serum, plasma, and cerebrospinal fluid studies. J. Alzheimers. Dis. 46, 75-87. doi: 10.3233/JAD-141296

Wang, Z. X., Tan, L., Wang, H. F., Ma, J., Liu, J., Tan, M. S., et al. (2015). Serum iron, zinc, and copper levels in patients with Alzheimer's disease: a replication study and meta-analyses. J. Alzheimers. Dis. 47, 565-581. doi: 10.3233/JAD143108
Xu, J., Begley, P., Church, S. J., Patassini, S., McHarg, S., Kureishy, N., et al. (2016). Elevation of brain glucose and polyol-pathway intermediates with accompanying brain-copper deficiency in patients with Alzheimer's disease: metabolic basis for dementia. Sci. Rep. 6:27524. doi: 10.1038/srep27524

Yuan, Y., Niu, F., Liu, Y., and Lu, N. (2014). Zinc and its effects on oxidative stress in Alzheimer's disease. Neurol. Sci. 35, 923-928. doi: 10.1007/s10072014-1668-x

Zappasodi, F., Salustri, C., Babiloni, C., Cassetta, E., Del Percio, C., Ercolani, M., et al. (2008). An observational study on the influence of the APOE-epsilon4 allele on the correlation between 'free' copper toxicosis and EEG activity in Alzheimer disease. Brain Res. 1215, 183-189. doi: 10.1016/j.brainres.2008.03.066

Conflict of Interest Statement: The authors declare that the research was conducted in the absence of any commercial or financial relationships that could be construed as a potential conflict of interest.

The reviewer BMM and handling Editor declared their shared affiliation.

Copyright (c) $2017 \mathrm{Li}$, Zhang, Wang and Zhao. This is an open-access article distributed under the terms of the Creative Commons Attribution License (CC BY). The use, distribution or reproduction in other forums is permitted, provided the original author(s) or licensor are credited and that the original publication in this journal is cited, in accordance with accepted academic practice. No use, distribution or reproduction is permitted which does not comply with these terms. 